\title{
Histochemical Properties of Skeletal Muscles in Different Body Parts of Young Japanese Black Steers
}

\author{
Takafumi GOTOH, Hisao IWAMOTO, Yoshitaka NAKANISHI ${ }^{1}$, \\ Raizaburo UMETSU ${ }^{2}$ and Yoshitaka $\mathrm{ONO}^{2}$ \\ Graduate school of Bioresouce and Bioenvironmental Science, Kyushu \\ University, Higashi-ku, Fukuoka-shi 812-8581, Japan \\ ${ }^{1}$ Faculty of Agriculture, Kagoshima University, Kagoshima-shi 890-0065, Japan \\ ${ }^{2}$ Kuju Agricultural Research Center, Kyushu University, \\ Kuju-machi, Oita-ken 878-0201, Japan
}

(Received May 13, 1999 ; Accepted July 27, 1999)

\begin{abstract}
Histochemical examination was carried out on the 66 skeletal muscles in the different body parts of the young Japanese Black steers (11 months of age). Tissues were taken from the central portion of each muscle, cut into serial frozen sections and stained by reactions for myosin ATPase and NADH dehydrogenase activities. Myofibers were divided into Type I, IIA and IIB. Generally the muscles in the young steers contained Type IIA myofibers at higher frequency as compared with the fattened adult. Some Type IIA myofibers seemed to transform into Type I or Type IIB with age. The muscles with much Type I myofibers which are to play a main role in posture maintaining were very small and occupied the deep position, but $\mathrm{Mm}$. serratus ventrales is fairly large. The large muscles important for beef production contained great proportion of Type II myofibers, which are mobilized to do more active motions such as locomotion. These results suggest that every muscle plays its peculiar function at different body parts after obtaining its own histochemical property.
\end{abstract}

Animal Science Journal 70 (6) : 497-509, 1999

Key words : Myofiber type, Japanese Black, Young steers, Skeletal muscle

More than 200 skeletal muscles play an important role in doing various body actions such as locomotion, postural maintenance, respiration, etc. Every muscle has an essential function in an articulation and is called as extensor, flexor, adductor, supinator, pronator muscle and so on. Coordinated contractions of the muscles to achieve an action make the body move smoothly and need for the different muscles to do various motions. With the different histochemical properties, the different muscles can move in different manners. Myofibers composing skeletal muscle are classified into three fundamental types, namely slowoxidative (SO), fast-twitch oxidative glycolytic (FOG), and fast-twitch glycolytic (FG) fibers ${ }^{12}$. The histochemical methods for classifying the myofiber types have been proposed by many authors $^{1,2,9)}$.

Motor units composed of SO myofibers are always mobilized at first to do endurance contraction for maintaining posture at minimum power. Development of a little larger power to do light work for long time is accomplished by the activation of motor units composed of FOG myofibers. Maximam power action during short term can be carried out under entry of the units composed of FG myofibers ${ }^{25}$. Myofiber type composition of each muscle could characterize its motion in stead of electromyographic investigation $^{26)}$. For example, the muscle composed of SO myofibers could play an important role for maintaining posture, and that composed of FG 


\section{GOTOH, IWAMOTO, NAKANISHI, UMETSU and ONO}

myofibers could be mobilized at the heavy action with strong power. In extremities, the muscle containing SO myofibers at high frequency takes deep position near bone and the superficial muscle contains great percentage of FG myofibers ${ }^{23)}$.

Japanese Black cattle are an important meat type for producing a good marbling beef consumed by Japanese traditional cooking. Although the histochemical properties of skeletal muscles in the fattened steer have been reported ${ }^{6,7,8)}$, the properties of the young steer before fattening have not been researched. The purpose of this research was to investigate myofiber type composition in the 66 muscles throughout the body of the young steers with the enzyme-histochemical methods and to clarify the relationship between the myofiber type distribution and the function of each individual muscle.

\section{Materials and Methods}

Three Japanese Black steers (11 months of age, body weight $181-277 \mathrm{~kg}$ ) were used in this study. After killing by bleeding from the carotid under anaesthesia with xylazine hydrochloride (Skillpen, Intervet International Inc.), the following 66 muscles were removed and weighed without peripheral adipose tissue and tendon.

1. Mm. colli et dorsi

M. sternothyroideus, $M$. spinalis et semispinalis thoracis et cervicis (M. spinalis), M. splenius (M. splenius cervicis), $M$. sternomastoideus ( $M$. sternocephalicus pars mastoidea), $M$. sternomandibularis ( $M$. sternocephalicus pars mandibularis), $M$. longissimus thoracis, $M$. longissimus capitis, $M$. semispinalis capitis and $M$. longus colli

\section{Mm. cinguli membri thoracici}

M. brachiocephalicus (pars occipitalis), M. trapezius, $M$. rhomboideus cervicis, $M$. rhomboideus thoracis, $M$. serratus ventralis cervicis, $M$. serratus ventralis thoracis, M. latissimus dorsi, $M$. pectoralis transversus, $M$. pectoralis descendens and $M$. pectoralis ascendens

3. Mm. membri thoracici

A. Scapular and Brachial Muscles

M. deltoideus (pars acromialis), M. supraspinatus, $M$. infraspinatus, $M$. subscapularis, $\boldsymbol{M}$. teres major, $\boldsymbol{M}$. triceps brachii ; caput longum, caput laterale, caput

Anim. Sci. J. 70 (6) : 497-509, 1999 mediale, $M$. biceps brachii and $\boldsymbol{M}$. brachialis

\section{B. Antebrachial Muscles}

M. extensor carpi radialis, $\boldsymbol{M}$. extensor digitorum communis, $M$. extensor digitorum lateralis, $M$. extesor carpi ulnaris, $M$. flexor carpi radialis, $M$. flexor carpi ulnaris, $\boldsymbol{M}$. flexor digitorum superficialis and $\boldsymbol{M}$. flexor digitorum profundus

\section{Mm. abdominis}

M. obliquus externus abdominis

5. Mm. memmbri pelvini

A. Hip and Thigh muscles

M. psoas major, M. iliacus, M.gluteus medius, $M$. gluteus accessorius, $M$. gluteus profundus, $M$. piriformis, $M$. gluteobiceps (Sampled at the center of $M$. biceps femoris pars cranialis), $M$. tensor fasciae latae, $M$. rectus femoris, $M$. vastus medialis, $M$. vastus lateralis, $M$. vastus intermedius, $M$. semitendinosus, $M$. semimembranosus, $M$. sartorius, $M$. gracilis, $M$. pectineus, and $M$. adductor

\section{B. Crusal muscles}

M. tibialis cranialis, $M$. peroneus tertius, $M$. peroneus longus, $M$. extensor digitorum longus, $M$. extensor digitorum lateralis $M$. gastrocnemius caput laterale, $M$. gastrocnemius caput mediale, M. soleus, M. flexor digitorum superficialis and $M$. flexor digitorum profundus

\section{Histochemistry}

Muscle samples (about $1 \mathrm{~cm}^{3}$ ) taken from the central region of each muscle were frozen in a mixture of dry ice-isopentane and stored at $-30^{\circ} \mathrm{C}$. Serial frozen sections ( $8 \mu \mathrm{m}$ thick) were cut transversely and stained by the histochemical reactions for reduced nicotine amide adenine dinucleotide dehydrogenase (NADH-DH) activities (Fig. 3) and myosin adenosine triphosphatase (ATPase) activities after acid ( $\mathrm{pH}$ 4.3) (Fig. 1) or alkaline ( $\mathrm{pH} \mathrm{10.5)} \mathrm{(Fig.} \mathrm{2)} \mathrm{preincu-}$ bation $^{2,19)}$. Myofibers were classified into Type I, IIA and IIB according to the method of Brooke and Kaiser $^{2)}$ (Figs. 1-3). Very few myofibers had a staining intensity of both acid and alkaline preincubation tissues in myosin ATPase activities (Fig. 1 and 2, arrows). Because of their low number, they were excluded from the analyses in this study.

\section{Statistical analysis}

Percentage distribution of myofiber types were cal- 
Myofiber Type Composition in Young Steers

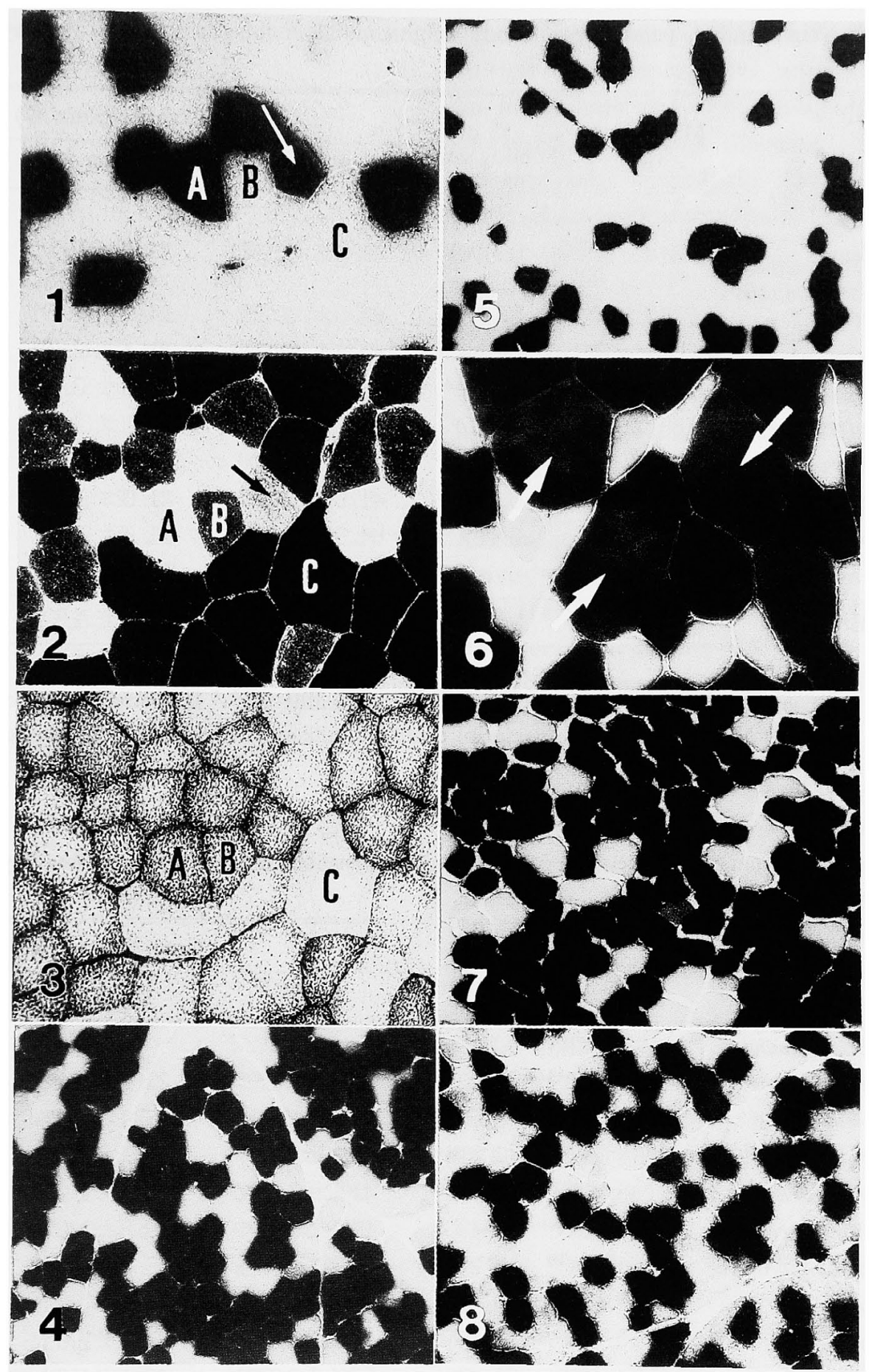

Figs. 1-3. Enzyme activities on the serial transverse sections in M. gluteus medius. $\times 100$. ATPase activity after preincubation at pH4.3 (Fig. 1). ATPase activity after preincubation at pH 10.5. (Fig. 2). Very few myofibers had myosin ATPase activities after both acid and alkaline preincubation (Figs. 1 and 2, arrows). NADH-dehydrogenase activity (Fig. 3). Type I, IIA and IIB myofibers are indicated as A, B and C respectively. Figs. 4-8. ATPase activity after acid preincubation. Fig. $4:$ M. spinaris et semispinalis thoracis et cervicis. $\times 50$. Fig. 5 : M. longissimus thoracis $\times 50$. Fig. $6:$ M. serratus ventralis thoracis. These arrows indicate Type SO-2 (or Type D) myofibers which were reported by Suzuki et al. ${ }^{15,24)}$. In this study Type SO-2 myofibers were categorized as Type I myofibers. $\times 100$. Fig. $7:$ M. gluteus profundus $\times 50$. Fig. $8:$ M. flexor digitorum superficialis $\times 50$. 
GOTOH, IWAMOTO, NAKANISHI, UMETSU and ONO

Table 1. Muscle weight and its percentage of body weight, myofiber type composition and myofiber diameter of steers

\begin{tabular}{|c|c|c|c|c|c|}
\hline \multirow{2}{*}{ Muscle } & \multirow{2}{*}{$\begin{array}{l}\text { Muscle wt. } \\
\quad(\mathrm{g})\end{array}$} & \multirow{2}{*}{$\begin{array}{l}\% \text { of } \\
\text { body wt. }\end{array}$} & \multicolumn{3}{|c|}{ Composition (\%) } \\
\hline & & & Type I & Type $\Pi$ A & Type II B \\
\hline \multicolumn{6}{|l|}{ Mm. colli et dorsi } \\
\hline M. sternothyroideus & $34 \pm 4^{b}$ & $0.014^{\mathrm{d}}$ & $42.0 \pm 3.5^{\times a b c}$ & $33.5 \pm 12.1^{\mathrm{xa}}$ & $24.5 \pm 14.8^{x a}$ \\
\hline $\begin{array}{l}\text { M. spinalis et semispinalis } \\
\text { thoracis et cervicis }\end{array}$ & $778 \pm 151^{b}$ & $0.316^{\mathrm{b}}$ & $62.3 \pm 3.2^{\mathrm{xab}}$ & $24.9 \pm 3.5^{\mathrm{ya}}$ & $12.8 \pm 6.5^{\mathrm{ya}}$ \\
\hline M. splenius & $299 \pm 78^{b}$ & $0.119^{\mathrm{bed}}$ & $40.3 \pm 1.5^{\mathrm{xabc}}$ & $21.4 \pm 2.7^{\mathrm{ya}}$ & $38.3 \pm 4.2^{\mathrm{xa}}$ \\
\hline M. sternomastoideus & $23 \pm 40^{b}$ & $0.095^{\mathrm{cd}}$ & $65.0 \pm 5.9^{\mathrm{xa}}$ & $19.8 \pm 3.6^{y a}$ & $15.2 \pm 6.4^{\mathrm{ya}}$ \\
\hline M. sternomadibularis & $165 \pm 30^{\mathrm{b}}$ & $0.067^{\mathrm{d}}$ & $35.6 \pm 2.4^{\mathrm{xbc}}$ & $28.1 \pm 2.7^{\mathrm{xa}}$ & $36.3 \pm 4.2^{\mathrm{xa}}$ \\
\hline M. longissimus thoracis & $3,101 \pm 617^{\mathrm{a}}$ & 1. $255^{\mathrm{a}}$ & $23.8 \pm 1.0^{y c}$ & $24.1 \pm 4.5^{y a}$ & $52.1 \pm 5.0^{\mathrm{xa}}$ \\
\hline M. longissimus capitis & $375 \pm 64^{\mathrm{b}}$ & $0.153^{\mathrm{bcd}}$ & $41.8 \pm 2.4^{\mathrm{xabc}}$ & $21.0 \pm 3.6^{y a}$ & $37.2 \pm 5.6^{\text {xya }}$ \\
\hline M. semispinalis capitis & $701 \pm 156^{b}$ & $0.282^{\mathrm{bc}}$ & $54.9 \pm 4.5^{\mathrm{xab}}$ & $21.6 \pm 5.3^{y a}$ & $23.5 \pm 1.5^{\mathrm{ya}}$ \\
\hline M. longus colli & * & $*$ & $60.4 \pm 12.8^{\mathrm{xab}}$ & $19.1 \pm 4.6^{y \mathrm{a}}$ & $20.5 \pm 11.7^{\mathrm{xya}}$ \\
\hline Mean \pm Standard Error & & & $47.3 \pm 4.7^{x}$ & $23.1 \pm 1.5^{y}$ & $28.9 \pm 4.3^{y}$ \\
\hline
\end{tabular}

$\mathrm{n}=3 \quad$ Mean \pm Standard Error.

* The sign of no data and a shortage of data to analyze statistically. $\mathrm{x}, \mathrm{Y}, \mathrm{Z}$ Mean with same superscript do not fibers $(P<0.05)$. $\quad a, b, c, d, c, f, g$ Mean with same superscript do not significantly differ between muscles $(P<0.05)$.

Table 2. Muscle weight and its percentage of body weight, myofiber type composition and myofiber diameter of Japanese black steers

\begin{tabular}{|c|c|c|c|c|c|}
\hline \multirow{2}{*}{ Muscle } & \multirow{2}{*}{$\begin{array}{l}\text { Muscle wt. } \\
\quad(\mathrm{g})\end{array}$} & \multirow{2}{*}{$\begin{array}{c}\% \text { of } \\
\text { body wt. }\end{array}$} & \multicolumn{3}{|c|}{ Composition (\%) } \\
\hline & & & Type I & Type II A & Type II B \\
\hline \multicolumn{6}{|l|}{ Mm. cinguli membri thoracici } \\
\hline M. brachiocephalicus & $652 \pm 107^{\mathrm{bcd}}$ & $0.267^{\circ}$ & $37.3 \pm 2.5^{\mathrm{xbc}}$ & $22.7 \pm 2.5^{y b}$ & $40.1 \pm 0.7^{\mathrm{xa}}$ \\
\hline M. trapezius & $501 \pm 94^{\mathrm{bcd}}$ & $0.203^{\mathrm{cd}}$ & $42.9 \pm 2.2^{x b c}$ & $23.9 \pm 0.8^{y b}$ & $33.3 \pm 2.9^{\mathrm{xab}}$ \\
\hline M. rhomboideus cervicis & $278 \pm 47^{\mathrm{cd}}$ & $0.114^{\mathrm{de}}$ & $32.4 \pm 1.1^{\mathrm{ybc}}$ & $27.1 \pm 3.7^{\mathbf{y b}}$ & $40.5 \pm 2.6^{\mathrm{xa}}$ \\
\hline M. rhomboideus thoracis & $240 \pm 55^{d}$ & $0.096^{\mathrm{de}}$ & 41. $2 \pm 2.2^{x b c}$ & $29.3 \pm 3.9^{\text {xyab }}$ & $29.6 \pm 1.7^{\text {yab }}$ \\
\hline M. serratus ventralis cervicis & $1,061 \pm 213^{a b}$ & $0.430^{b}$ & 45. $3 \pm 9.0^{x b c}$ & $28.8 \pm 2.9^{\mathrm{xab}}$ & $27.2 \pm 10.2^{\text {xabc }}$ \\
\hline M. serratus ventralis thoracis & $618 \pm 143^{\mathrm{bcd}}$ & $0.248^{\mathrm{c}}$ & $51.0 \pm 3.4^{\mathrm{xab}}$ & $45.0 \pm 5.2^{\mathrm{xa}}$ & $3.7 \pm 1.9^{y c}$ \\
\hline M. latissimus dorsi & $961 \pm 161^{\mathrm{abc}}$ & $0.393^{b}$ & $30.4 \pm 0.9^{x c}$ & $34.6 \pm 1.3^{\mathrm{xab}}$ & $35.0 \pm 1.9^{\text {xab }}$ \\
\hline M. pectoralis transversus & $475 \pm 113^{\text {bcd }}$ & $0.191^{\mathrm{cd}}$ & $28.6 \pm 3.8^{y b c}$ & $24.3 \pm 1.5^{y b}$ & $47.0 \pm 4.6^{\times a}$ \\
\hline M. pectoralis descendens & $188 \pm 43^{d}$ & $0.076^{e}$ & $67.7 \pm 2.2^{\text {ха }}$ & $20.1 \pm 4.8^{y b}$ & $12.2 \pm 6.9^{y b}$ \\
\hline M. pectoralis ascendens & $1,523 \pm 254^{\mathrm{a}}$ & $0.622^{\mathrm{a}}$ & $31.8 \pm 3.4^{x c}$ & $31.0 \pm 1.3^{\mathrm{xab}}$ & $37.2 \pm 3.6^{\mathrm{xabc}}$ \\
\hline Mean \pm Standard Error & & & $41.1 \pm 3.7^{x}$ & $29.3 \pm 2.2^{y}$ & $29.6 \pm 3.9^{y}$ \\
\hline
\end{tabular}

$\mathrm{n}=3$ Mean \pm Standard Error. ${ }^{a}, b, c, d, e, x, y, *$ See the foot notes of Table 1. 


\section{Myofiber Type Composition in Young Steers}

each type in $\mathbf{M m}$. colli et dorsi in young Japanese black

\begin{tabular}{ccc}
\hline & \multicolumn{2}{c}{ Diameter $(\mu \mathrm{m})$} \\
\hline Type I & Type II A & Type II B \\
\hline & & \\
$47.2 \pm 6.4^{\mathrm{xa}}$ & $43.0 \pm 5.4^{\mathrm{xa}}$ & $39.9 \pm 10.4^{*}$ \\
$41.7 \pm 4.5^{\mathrm{xa}}$ & $38.4 \pm 5.6^{\mathrm{xa}}$ & $40.9 \pm 6.6^{\mathrm{xa}}$ \\
$35.1 \pm 2.0^{\mathrm{xa}}$ & $32.4 \pm 2.9^{\mathrm{xa}}$ & $36.5 \pm 5.0^{\mathrm{xa}}$ \\
$35.0 \pm 3.5^{\mathrm{xa}}$ & $29.2 \pm 3.3^{\mathrm{xa}}$ & $33.2 \pm 5.7^{\mathrm{xa}}$ \\
$28.7 \pm 2.0^{\mathrm{xa}}$ & $25.0 \pm 1.5^{\mathrm{xa}}$ & $28.6 \pm 2.3^{\mathrm{xa}}$ \\
$40.9 \pm 6.6^{\mathrm{xa}}$ & $42.4 \pm 3.9^{\mathrm{xa}}$ & $56.6 \pm 5.4^{\mathrm{xa}}$ \\
$33.7 \pm 3.5^{\mathrm{xa}}$ & $28.6 \pm 2.6^{\mathrm{xa}}$ & $29.4 \pm 3.2^{\mathrm{xa}}$ \\
$35.8 \pm 1.0^{\mathrm{xa}}$ & $30.9 \pm 3.0^{\mathrm{xa}}$ & $33.6 \pm 6.2^{\mathrm{xa}}$ \\
$43.7 \pm 5.3^{\mathrm{xa}}$ & $31.9 \pm 3.0^{\mathrm{xa}}$ & $36.6 \pm 4.0^{*}$ \\
\hline $38.0 \pm 1.9^{\mathrm{x}}$ & $33.6 \pm 2.1^{\mathrm{x}}$ & $37.3 \pm 2.8^{\mathrm{x}}$ \\
\hline
\end{tabular}

significantly differ between Type I, II A and II B myo-

each type in $M m$. cinguli membri thoracici in young

\begin{tabular}{|c|c|c|}
\hline \multicolumn{3}{|c|}{ Diameter $(\mu \mathrm{m})$} \\
\hline Type I & Type II A & Type II B \\
\hline $36.6 \pm 3.6^{\mathrm{xa}}$ & $38.3 \pm 4.6^{x a}$ & $45.3 \pm 6.0^{\times a}$ \\
\hline $44.5 \pm 3.3^{x a}$ & $43.2 \pm 3.6^{\mathrm{xa}}$ & $54.1 \pm 4.2^{\mathrm{xa}}$ \\
\hline $38.1 \pm 3.2^{\mathrm{xa}}$ & $38.3 \pm 3.4^{\mathrm{xa}}$ & $47.1 \pm 5.9^{x a}$ \\
\hline $47.8 \pm 8.2^{x a}$ & $43.7 \pm 9.3^{x a}$ & $51.0 \pm 9.4^{x a}$ \\
\hline $50.1 \pm 2.9^{\mathrm{xa}}$ & $41.4 \pm 2.4^{\mathrm{xa}}$ & $44.8 \pm 3.1^{\mathrm{xa}}$ \\
\hline $49.6 \pm 7.7^{x a}$ & $34.0 \pm 5.5^{x a}$ & $26.6 \pm 7.1 *$ \\
\hline $43.4 \pm 3.8^{x a}$ & $45.1 \pm 4.2^{\mathrm{xa}}$ & $55.4 \pm 6.8^{x a}$ \\
\hline $38.8 \pm 2.1^{\mathrm{xa}}$ & $43.5 \pm 3.0^{\mathrm{xa}}$ & $49.3 \pm 3.5^{\times a}$ \\
\hline $52.6 \pm 4.1^{\mathrm{xa}}$ & $46.3 \pm 6.4^{x a}$ & $46.6 \pm 7.3^{*}$ \\
\hline $40.6 \pm 3.6^{\mathrm{xa}}$ & $39.1 \pm 3.4^{\mathrm{xa}}$ & $46.5 \pm 5.2^{\mathrm{xa}}$ \\
\hline $44.2 \pm 1.8^{x}$ & $41.3 \pm 1.2^{x}$ & $46.7 \pm 2.5^{x}$ \\
\hline
\end{tabular}

culated on the 600 or more myofibers in each muscle. In every myofiber type, the largest width perpendicular to the long axis of maximum 100 myofibers was measured as myofiber diameter ${ }^{3)}$. The analyses of variance were carried out with Tukey or Scheffe's methods among the muscles.

\section{Results}

\section{Myofiber types}

Type I myofibers stained strongly with NADH-DH, had strong myosin ATPase activities after acid preincubation and weak myosin ATPase activities after alkaline preincubation. On the other hand, Type II (IIA and IIB) myofibers showed a weak myosin ATPase activity after acid preincubation and a strong activity after alkaline preincubation (Figs. 1 and 2 ). Type II myofibers were divided into Type IIA and IIB myofibers according to NADH-DH activities. Type IIA myofibers were reactive to NADH-DH and Type IIB were unreactive (Fig. 3).

In some muscles, including the $M$. serratus ventralis thoracis, Type SO-2 (or Type D) myofibers reported by Suzuki et al. ${ }^{15,24)}$ were observed. Type SO-2 myofibers, subtype of Type I, show reticular pattern of diformazan deposits in NADH-DH activities and have large diameter (Fig, 6, arrow). But, in this study, these myofibers were categorized as Type I myofibers.

\section{Mm. colli et dorsi}

Except for $M$. longissimus thoracis, the other muscles in this group are located mainly at the neck part and play a major role in moving the neck and suspend the head. Of all the neck muscles, the largest weight was indicated by $M$. spinalis et semispinalis thoracis et cervicis $(778 \mathrm{~g})$, the second largest by $M$. semispinalis $(701 \mathrm{~g}$ ) (Table 1 ). The weight of $M$. longissimus thoracis was $3,101 \mathrm{~g}$, the second largest of all the body muscles following after that of $M$. gluteobiceps, 3,203 g, the largest. In the fattened steers, it was reported by Iwamoto et $a l^{8)}$ and Gotoh et al. ${ }^{6,7)}$ that $M$. longissimus thoracis is larger than $M$. gluteobiceps. These different results indicate the difference in maturing growth rates between the two muscles, the former matures later, while the latter matures earlier. 


\section{GOTOH, IWAMOTO, NAKANISHI, UMETSU and ONO}

Table 3. Muscle weight and its percentage of body weight, myofiber type composition and myofiber diameter of black steers

\begin{tabular}{|c|c|c|c|c|c|}
\hline \multirow{2}{*}{ Muscle } & \multirow{2}{*}{$\begin{array}{c}\text { Muscle wt. } \\
\text { (g) }\end{array}$} & \multirow{2}{*}{$\begin{array}{c}\% \text { of } \\
\text { body wt. }\end{array}$} & \multicolumn{3}{|c|}{ Composition $(\%)$} \\
\hline & & & Type I & Type II A & Type II B \\
\hline \multicolumn{6}{|l|}{ Mm. membri thoracici } \\
\hline \multicolumn{6}{|l|}{ 1. Scapular and Brachial Muscles } \\
\hline M. deltoideus & $191 \pm 32^{\mathrm{cd}}$ & $0.078^{\mathrm{ef}}$ & $24.6 \pm 1.9^{\mathrm{yb}}$ & $26.6 \pm 4.1^{y a}$ & $48.8 \pm 2.2^{x a}$ \\
\hline M. supraspinatus & $661 \pm 118^{\mathrm{bc}}$ & $0.269^{b c}$ & $48.9 \pm 5.3^{\mathrm{xa}}$ & $32.3 \pm 6.5^{\mathbf{x a}}$ & $18.9 \pm 10.2^{\mathrm{xa}}$ \\
\hline$M$. infraspinatus & $811 \pm 157^{\circ}$ & $0.331^{b}$ & $44.8 \pm 5.4^{\mathrm{xab}}$ & $29.9 \pm 8.4^{\mathrm{xa}}$ & $24.5 \pm 12.2^{\mathrm{xa}}$ \\
\hline M. subscapularis & $471 \pm 79^{\mathrm{bed}}$ & $0.193^{\mathrm{cd}}$ & $38.0 \pm 1.2^{\mathrm{xab}}$ & $23.7 \pm 3.9^{y a}$ & $38.3 \pm 3.4^{x y a}$ \\
\hline M. teres major & $174 \pm 33^{\mathrm{cd}}$ & $0.07]^{\text {ef }}$ & $31.3 \pm 6.8^{x a b}$ & $34.3 \pm 2.7^{x a}$ & $34.3 \pm 1.1^{\text {xa }}$ \\
\hline \multicolumn{6}{|l|}{ M. triceps brachii } \\
\hline Caput longum & $1,360 \pm 233^{\mathrm{a}}$ & $0.556^{\mathrm{a}}$ & 33.2 & 25.5 & 41.3 \\
\hline Caput laterale & $299 \pm 60^{\mathrm{bcd}}$ & $0.121^{\mathrm{de}}$ & $45.5 \pm 3.9^{\mathrm{xab}}$ & $29.9 \pm 8.4^{\mathrm{xa}}$ & $24.6 \pm 12.2^{\mathrm{xa}}$ \\
\hline Caput mediale & $40 \pm 7^{d}$ & $0.017^{\mathrm{f}}$ & 83.5 & 16.5 & 0 \\
\hline M. biceps brachii & $243 \pm 48^{\mathrm{cd}}$ & $0.099^{e}$ & $39.1 \pm 3.3^{x a b}$ & $27.6 \pm 2.0^{y a}$ & $33.2 \pm 4.1^{\mathrm{xya}}$ \\
\hline M. brachialis & $199 \pm 30^{\mathrm{ed}}$ & $0.082^{e}$ & $42.3 \pm 5.8^{\mathrm{xab}}$ & $30.1 \pm 8.7^{\mathrm{xa}}$ & $27.6 \pm 7.8^{x a}$ \\
\hline Mean \pm Standard Error & & & 43. $1 \pm 5.0^{x}$ & $27.7 \pm 1.6^{y}$ & $32.4 \pm 3.2^{x y}$ \\
\hline \multicolumn{6}{|l|}{ 2. Antebrachial Muscles } \\
\hline$M$. extensor carpi radialis & $332+51^{a}$ & $0.137^{a}$ & $20.9 \pm 2.4^{\mathrm{yb}}$ & $23.6 \pm 3.5^{\mathrm{ya}}$ & $55.5 \pm 2.9^{x a}$ \\
\hline M. extensor digitorum communis & $90 \pm 17^{b}$ & $0.037^{\mathrm{bc}}$ & $26.5 \pm 1.5^{*}$ & $37.9 \pm 3.9^{*}$ & $35.9 \pm 5.4^{*}$ \\
\hline$M$. extensor digitorum lateralis & $72 \pm 18^{b}$ & $0.029^{c}$ & $21.8 \pm 3.4^{y b}$ & $31.9 \pm 3.2^{\mathrm{ya}}$ & $46.3 \pm 1.1^{\mathrm{xa}}$ \\
\hline M. extensor carpi ulnaris & $128 \pm 22^{b}$ & $0.053^{b}$ & $52.9 \pm 3.1^{x a}$ & $47.1 \pm 3.1^{\mathrm{xa}}$ & - \\
\hline M. flexor carpi radialis & $52 \pm 4^{b}$ & $0.022^{c}$ & $31.2 \pm 3.1^{x b}$ & $41.7 \pm 16.7^{\mathrm{xa}}$ & $27.2 \pm 13.6^{x a b}$ \\
\hline M. flexor carpi ulnaris & $56 \pm 11^{b}$ & $0.023^{c}$ & $52.6 \pm 7.8^{x a}$ & 43. $4 \pm 9.9^{\mathrm{xa}}$ & $4.0 \pm 2.2^{\mathrm{yb}}$ \\
\hline M. flexor digitorum superficialis & $91 \pm 16^{b}$ & $0.037^{b c}$ & $58.4 \pm 2.2^{x a}$ & $41.6 \pm 2.2^{\mathrm{ya}}$ & 0 \\
\hline M. flexor digitorum profundus & $315 \pm 38^{a}$ & $0.131^{\mathrm{a}}$ & $33.1 \pm 0.4^{y b}$ & $26.1 \pm 1.3^{\mathrm{za}}$ & $40.8 \pm 1.6^{\mathrm{xa}}$ \\
\hline Mean \pm Standard Error & & & $37.2 \pm 5.4^{x}$ & $36.7 \pm 3.0^{x}$ & $35.0 \pm 7.3^{x}$ \\
\hline
\end{tabular}

$\mathrm{n}=3$ Mean \pm Standard Error. a, b, c, d, e, $, \mathrm{x}, \mathrm{y}, \mathrm{z} *$ See the foot notes of Table 1 .

For the head suspension, $M$. semispinalis capitis and M. spinalis et semispinalis thoaracis et cervicis (Fig. 4) were important muscles keeping their superior position from the vertebral column and containing a half or more of Type I myofibers (Table 1). On the other hand, $M$. longus colli also contained $60 \%$ of Type I myofibers in spite of its inferior position from the column, an antagonist to the former. Although $M$. sternomastoideus and $M$. sternomandibularis make up $M$. sternocephalicus together, the myofiber composition differed much between them, that is, the former contained Type I myofibers twice as many as the latter. In the dorsal and lumber part, $M$. longissimus thoracis were composed of $52 \%$ of Type IIB, $24 \%$ of Type IIA and $24 \%$ of Type I (Fig. 5) and show the myofiber composition differed from the neck muscles.

The myofiber diameters of Mm. colli et dorsi, showed no significant differences among the muscles.

Mm. cinguli membri thoracici

Of all the cingulum muscles, the $M$. pectoralis ascendens $(1,523 \mathrm{~g})$ showed the heaviest weight followed by $M$. serrarus ventralis cervicis $(1,061 \mathrm{~g})$, and by $M$. latissimus dorsi (961 g) (Table 2). The combined weights of the three pectoralis muscles and 


\section{Myofiber Type Composition in Young Steers}

each type in $\mathrm{Mm}$. membri thoracici in young Japanese

\begin{tabular}{ccc}
\hline & Diameter $(\mu \mathrm{m})$ & \\
\hline Type I & Type II A & Type II B \\
\hline
\end{tabular}

\begin{tabular}{|c|c|c|}
\hline $36.9 \pm 1.5^{y a}$ & $43.6 \pm 3.4^{x y a}$ & $56.3 \pm 4.4^{\mathrm{xa}}$ \\
\hline $47.7 \pm 5.0^{\mathrm{xa}}$ & $41.6 \pm 4.8^{\mathrm{xa}}$ & $42.4 \pm 3.4^{x a}$ \\
\hline $52.0 \pm 2.8^{\mathrm{xa}}$ & $43.8 \pm 0.9^{y a}$ & $50.3 \pm 1.9^{x a}$ \\
\hline $47.9 \pm 5.9^{\times a}$ & $49.6 \pm 5.5^{\mathrm{xa}}$ & $56.4 \pm 5.6^{\mathrm{xa}}$ \\
\hline $49.6 \pm 10.5^{\times a}$ & $48.2 \pm 5.4^{\mathrm{xa}}$ & $54.6 \pm 4.1^{x a}$ \\
\hline 28.9 & 25.4 & 31. 8 \\
\hline $53.7 \pm 6.6^{\text {xa }}$ & 48. $1 \pm 1.3^{x a}$ & $57.9 \pm 3.6^{x a}$ \\
\hline 31.5 & 26.2 & - \\
\hline $40.4 \pm 3.9^{\times a}$ & 41. $8 \pm 4.4^{x a}$ & $48.0 \pm 3.8^{x a}$ \\
\hline $52.4 \pm 1.9^{\times a}$ & $45.5 \pm 0.8^{\text {ya }}$ & $50.9 \pm 1.1^{x a}$ \\
\hline 44. $1 \pm 2.9^{x y}$ & $41.4 \pm 2.7^{y}$ & $49.8 \pm 2.8^{x}$ \\
\hline $40.9 \pm 4.3^{x a}$ & $43.2 \pm 5.0^{\mathrm{xa}}$ & $55.2 \pm 6.3^{x a}$ \\
\hline 59.6 & 53.6 & 58.9 \\
\hline 43. $2 \pm 7.8^{x a}$ & $45.1 \pm 10.1^{x a}$ & $56.4 \pm 9.7^{\mathbf{x a}}$ \\
\hline $50.5 \pm 8.7^{\mathrm{xa}}$ & $49.1 \pm 9.2^{\mathrm{xa}}$ & - \\
\hline $47.9 \pm 4.9^{x a}$ & $49.2 \pm 4.2^{\mathrm{xa}}$ & $49.5 \pm 5.3^{*}$ \\
\hline $46.7 \pm 4.5^{x a}$ & $51.5 \pm 6.7^{\times a}$ & $47.5 \pm 12.0^{*}$ \\
\hline $52.2 \pm 2.2^{x^{\mathrm{a}}}$ & $51.4 \pm 2.9^{x a}$ & - \\
\hline $48.2 \pm 0.7^{y^{2}}$ & $49.3 \pm 1.5^{x y z}$ & $60.2 \pm 4.0^{x a}$ \\
\hline 48. $7 \pm 2.0^{x y}$ & $49.1 \pm 1.2^{y}$ & $54.6 \pm 2.1^{x}$ \\
\hline
\end{tabular}

the two serratus ( $M$. serratus ventralis cervicis and $M$. serratus ventaralis thoracis) were $2,186 \mathrm{~g}$ and $1,679 \mathrm{~g}$, respectively.

In the pectoralis muscles, the different myofiber compositions indicated the regional and functional specialization. $M$. pectoralis descendens containing. $68 \%$ of Type I myofibers with larger dimension played a main role in posture maintaining and occupied the smallest part (188 g). The other two large parts $(M$. pectoralis ascendens : $1,523 \mathrm{~g}, M$. pectoralis transversus $: 475 \mathrm{~g}$ ) were composed of large percentage of fasttwitch myofibers (Table 2). In both the serratus ventralis, half myofibers were recognized as Type I with large dimension (Fig. 6), as these muscles work especially for suspending trunk between both thoracic extremities. In $M$. latissimus dorsi, the three myofiber types were similar in percentage and Type IIB had the largest size.

\section{Mm. membri thoracici}

\section{(1) Scapular and brachial muscles}

In this group, the heaviest weight was shown by $M$. triceps brachii $(1,699 \mathrm{~g})$ which made up of the caput longum $(1,360 \mathrm{~g})$, the caput laterale $(299 \mathrm{~g})$, and the caput mediale $(40 \mathrm{~g})$. The second heaviest weight was observed in $M$. infraspinatus, and the third in $M$. supraspinatus.

In $M$. triceps brachii, the caput mediale had high percentage of Type I myofibers and the caput longum low percentages of Type I myofibers, whereas Type I myofibers accounted for about $50 \%$ in the caput laterale. These caputs could be engaged in different functions. $M$. infraspinatus and $M$. supraspinatus outside of scapular bone contained well developed Type I myofibers at high percentage. In $M$. deltoideus which occupied the most superficial position of scapular region, $75 \%$ of myofibers were fast-twitch and two thirds of those exhibited low NADH-DH activity.

\section{(2) Antebrachial muscles}

M. extensor carpi radialis, only a carpus extensor has obtained larger weight $(332 \mathrm{~g})$ than the total weight of three flexor muscles (total $236 \mathrm{~g} ; M$. extensor carpi ulnaris, $M$. flexor carpi ulnaris and $M$. flexor carpi radialis). The total weight $(406 \mathrm{~g})$ of the two flexor digitalis (M. flexor digitorum superficialis and M. flexor digitorum profundus) were 2.5 times as large as the two extensor ( $M$. extensor digitorum communis and $M$. extensor digitorum lateralis) (162 g). In these four muscles, $M$. flexor digitorum profundus had obtained the largest weight ( $315 \mathrm{~g}$ ) (Table 3).

In $M$. flexor digitorum superficialis, $M$. extensor carpi ulnaris and $M$. flexor carpi ulnaris, almost all the myofibers were red myofibers, $58 \%$ in the former and $53 \%$ in the latter two of which were Type I (Table 3). The other muscles were characterized by low percentages of Type I myofibers (21-33\%). In $M$. extensor carpi radialis and $M$. extensor digitorum lateralis, half 


\section{GOTOH, IWAMOTO, NAKANISHI, UMETSU and ONO}

myofibers were categorized as Type IIB category. General myofiber sizes in this region were large (Type I, $49 \mu \mathrm{m}$, IIA, $49 \mu \mathrm{m}$, IIB, $55 \mu \mathrm{m})$ and indicated earlier maturing muscles (Table 3 ).

\section{Mm. abdominis}

M. obliquus externus abdominis is a thin and broad muscle in the abdominal wall and had a weight of 782 g. The myofiber type distribution was characterized by low percentage of Type IIA myofibers (14\%) and about even distribution of the other two types (Table 4).

\section{Mm. membri pelvini}

(1) Hip and thigh muscles

This part was composed of many large muscles and seemed to be very important for quantitative beef production. Of all the body muscles, $M$. gluteobiceps was the largest $(3,203 \mathrm{~g})$. The second largest in this part was $M$. quadriceps femoris $(2,624 \mathrm{~g}$ ) made up of the four heads, namely $M$. vastus lateralis $(1,021 \mathrm{~g})$, M. rectus femoris $(940 \mathrm{~g}), M$. vastus medialis $(530 \mathrm{~g})$ and $M$. vastus intermedius $(133 \mathrm{~g})$. The third was $M$. semimembranosus $(2,242 \mathrm{~g})$, followed by the gluteus muscle group $(1,179 \mathrm{~g})$ and $M$. semitendinosus $(1,169$ g) (Table 5).

In the four small muscles, $M$. vastus intermedius, $M$. gluteus accessorius, $M$. gluteus profundus (Fig. 7) and M. iliacus, 62-97\% of myofibers were Type I. On the other hand, large muscles such as $M$. semimembranosus, $M$. rectus femoris, $M$. semitendinosus and $M$. gluteobiceps, contained Type I myofibers at low frequancy $(21-31 \%)$. In the quadriceps and the gluteus muscles, Type IIA, IIB myofibers were recongnized at three fourths of all or more in the superficial large heads.

On the red muscles, $\boldsymbol{M}$. gluteus profundus and $\boldsymbol{M}$. gluteus accessorius were well developed with larger size myofibers. M. semitendinosus, a white muscle, attained the largest size Type IIB myofibers and its Type IIA myofibers were also well developed (Table 5). In every myofiber type, the diameter showed a wide range among the muscles except for $M$. vastus lateralis and $M$. vastus intermedius such as 23 (34 to 57) $\mu \mathrm{m}$ in Type $\mathrm{I}, 18$ ( 36 to 54 ) $\mu \mathrm{m}$ in Type IIA and 28 (41 to 69) $\mu \mathrm{m}$ in Type IIB. These results seemed to indicate the characteristics of myofiber in a growing steer.

\section{(2) Crusal muscles}

Strong tarsus extensor, $M$. triceps surae, weighing $819 \mathrm{~g}$ was composed of the caput laterale $(441 \mathrm{~g})$ and the caput mediale $(372 \mathrm{~g})$ of $M$. gastrocnemius and $M$. soleus $(6 \mathrm{~g})$ (Table 5). This triceps muscle weight was 3.4 times as much as the total weight of the flexor muscle group ( $\boldsymbol{M}$. tibialis cranialis, $\boldsymbol{M}$. peroneus tertius and $M$. peroneus longus) (Table 5 ). On the other hand, a converse relation was recognized in the digitalis muscles, where the flexor group gained a weight of $526 \mathrm{~g}$, indicating 2.1 times as much as the extensor (245 g).

Type I myofibers were distributed in $M$, soleus at high frequency (86\%). Both caputs of $M$. gastrocnemius, however, were composed of $22-30 \%$ of Type I, 34-36\% of Type IIA, 34-45\% of Type IIB myofibers. In the antagonist muscle group, $M$. tibialis cranialis taking the deepest position near tibia bone contained $59 \%$ of myofibers as Type I and conversely $\boldsymbol{M}$. peroneus tertius in the superficial had $37 \%$ of myofibers of the same type. In $M$. flexor digitorum superfiscialis, the myofibers were almost red (Type I, 39\%, Type IIA, 49\%). However, another digitalis flexor ( $M$. flexor digitorum profundus) contained the three myofibers at even percentages. The digitalis extensor muscles showed $22-38 \%$ of Type $\mathbf{I}$,

Table 4. Muscle weight and its percentage of body weight, myofiber type composition and myofiber diameter of steers

\begin{tabular}{ccccc} 
Muscle & $\begin{array}{c}\text { Muscle wt. } \\
(\mathrm{g})\end{array}$ & $\begin{array}{c}\% \text { of } \\
\text { body wt. }\end{array}$ & Type I & Composition (\%) \\
\cline { 4 - 5 } & & & Type II A
\end{tabular}

Type II B

Mm. abdominis

M. obliquus externus abdominis $\quad 782 \pm 144 \quad 0.318 \quad 40.2 \pm 6.2^{x} \quad 13.9 \pm 2.3^{y} \quad 45.9 \pm 5.1^{x}$

$\mathrm{n}=3 \quad$ Mean \pm Standard Error. ${ }^{x, y}$ See the foot notes of Table 1.

Anim. Sci. J. 70 (6) : 499-509, 1999 
$25-32 \%$ of Type IIA and $36-46 \%$ of Type IIB myofibers.

\section{Discussion}

Type I myofibers are distributed in every muscles in domestic animals, such as cattle ${ }^{6,7,8,18,28)}$, pig $^{4,13,20)}$, sheep ${ }^{14,15,17,23,24)}$, goat ${ }^{(1)}$ and horse ${ }^{10)}$. In chicken, however, the large muscles such as $M$. pectoralis, $M$. supracoracoidues and $M$. iliotibialis lateralis are mainly composed of Type II myofibers ${ }^{16,22)}$. The proportional distribution of myofiber types differs among individual muscles and parts of each muscle, especially large muscle, in cattle $e^{6,7)}$. Myofiber type composition and diameter at the central region of each muscle fairly exhibit the functional characteristic.

A cattle keeps its heavy head always high by sustaining function of the cervical muscles. In $M$. spinalis et semispinalis thoracis et cervicis (Fig. 4) and $M$. semispinalis capitis related to the function on vertebral column, half or more myofibers were categorized as Type I (Table 1). M. longus colli, an antagonist against $M$. spinalis et semispinalis thoracis et cervicis and $M$. semispinalis capitis, also contained over half myofiber as Type I. Accordingly, M. longus colli seems to play mainly another function other than as antagonist, namely maintaining cervical and thoracic vertebral column in appropriate position.

For supporting the gravity of standing cattle, thoracic and pelvic extremities are kept straight with a little energy expenditure while strong tendons of $\mathrm{Mm}$. flexor digitales superficiales are pulled by the overextension of the fetlock and phalangeal joints ${ }^{5}$. The gravity are distributed more on the thoracic. However, the muscle in the thoracic was half of that in the pelvic in weight. The percentage of Type I myofibers in the muscle was $58.4 \%$ in the thoracic and $38.5 \%$ in each type in Mm. abdominis in young Japanese black

\begin{tabular}{ccc}
\hline \multicolumn{3}{c}{ Diameter $(\mu \mathrm{m})$} \\
Type I & Type II A & Type II B \\
\hline $40.0 \pm 6.8^{x}$ & $40.0 \pm 7.6^{x}$ & $49.1 \pm 8.5^{x}$ \\
\hline
\end{tabular}

Anim. Sci. J. 70 (6) : 497-509, 1999 the pelvic (Tables 3,5). These results suggested that the superficial flexor muscle in the pelvic has also attained the ability of producing strong power to kick off ground for locomotion.

Of the 19 femoral muscles, the largest $M$. gluteobiceps, the second $M$. semimembranosus and the third $M$. semitendinosus occupied altogether $45 \%$ of the total volume. All these three muscles take postfemoral position and work as extensor at hip joint and flexor at stifle joint to push cattle forward. A huge number of long myofibers contained in these strap or unipennate muscles were placed into the category of Type I at $21.3-30.7 \%$, Type IIA at $27.8-40.0 \%$ and Type IIB at $25.5-42.9 \%$, where two thirds or more of the myofibers were fast-twitch (Table 5). On the other hand, in $\boldsymbol{M}$. vastus intermedius, $\boldsymbol{M}$. gluteus accessorius, $\boldsymbol{M}$. gluteus profundus and $M$. iliacus, more than half myofibers $(61.7-97.2 \%)$ were recognized as Type I (Table 5). It was indicated that these small muscles occupied deep position of femoral part play a main role at posture maintaining.

In pelvic extremity, both caputs of $\boldsymbol{M}$. gastrocnemius, a strong extensor at tarsal joint, contain a great proportion of Type II (fast-twitch) myofibers and could produce strong power for locomotion. Its small three antagonists, $M$. tibialis cranialis, $M$. peroneus tertius and $M$. peroneus longus exhibited larger percentage of Type I myofibers than $M$. gastrocnemius. As flexor at tarsal joint, these muscles don't seem to play sustaining function of the gravity. While tarsal joint always keeps at an angle able to run away as soon as a cattle catches danger, these flexor muscles could play a function to maintain tarsal joint its condition resisting to extension power exerted by M. gastrocnemius and M. flexor digitalis superficialis. However, as tarsal joint is important and active to do locomotion, these flexors contained half myofibers as Type II (Fig. 8). In the thoracic extremity, only an extensor of carpal joint, $M$. extensor carpi radialis, was composed of $20.9 \%$ Type I, 23.6\% Type IIA and 55.5\% Type IIB myofibers. In two of the three flexor muscles, $M$. extensor carpi ulnaris (In spite of being named for " $M$. extensor", this muscle functioned as "M. flexor" in ruminant and horse.) and $M$. flexor carpi ulnaris, half myofibers were Type I and the 


\section{GOTOH, IWAMOTO, NAKANISHI, UMETSU and ONO}

Table 5. Muscle weight and its percentage of body weight, myofiber type composition and myofiber diameter of black steers

\begin{tabular}{|c|c|c|c|c|c|}
\hline \multirow{2}{*}{ Muscle } & \multirow{2}{*}{$\begin{array}{l}\text { Muscle wt. } \\
\quad(\mathrm{g})\end{array}$} & \multirow{2}{*}{$\begin{array}{c}\% \text { of } \\
\text { body wt. }\end{array}$} & \multicolumn{3}{|c|}{ Composition $(\%)$} \\
\hline & & & Type I & Type II A & Type II B \\
\hline \multicolumn{6}{|l|}{ Mm. membri pelvini } \\
\hline \multicolumn{6}{|l|}{ 1. Femural Muscles } \\
\hline M. psoas major & $832 \pm 126^{b c}$ & $0.343^{\mathrm{cf}}$ & $44.8 \pm 3.3^{\mathrm{xabc}}$ & $27.8 \pm 0.8^{y a t}$ & $27.3 \pm 4.0^{\mathrm{yab}}$ \\
\hline M. iliacus & $361 \pm 47^{\circ}$ & $0.149^{\mathrm{ccg}}$ & $61.7 \pm 8.2^{\mathrm{xab}}$ & $22.1 \pm 8.4^{\mathrm{yab}}$ & 16. $2 \pm 3.2^{y b}$ \\
\hline$M$. gluteus medius & $915 \pm 210^{b c}$ & $0.370^{\mathrm{ce}}$ & $28.5 \pm 5.6^{\mathrm{xc}}$ & $44.2 \pm 2.9^{\times a}$ & $27.3 \pm 8.5^{\mathrm{xab}}$ \\
\hline M. gluteus accessorius & $112 \pm 19^{c}$ & $0.046^{\mathrm{g}}$ & $72.4 \pm 1.6^{\mathrm{xa}}$ & 13. $2 \pm 4.3^{y b}$ & 14. $5 \pm 4.5^{y^{\mathrm{b}}}$ \\
\hline M. gluteus profundus & $152 \pm 27^{c}$ & $0.063^{\circ}$ & $68.0 \pm 1.3^{\mathrm{xab}}$ & $15.6 \pm 2.3^{y b}$ & $16.4 \pm 3.2^{y^{b}}$ \\
\hline M. piriformis & $626 \pm 87^{\circ}$ & $0.260^{\text {cdefg }}$ & $25.1 \pm 1.6^{y c}$ & $35.7 \pm 2.2^{\mathrm{xab}}$ & $39.2 \pm 3.7^{\mathrm{xab}}$ \\
\hline M. gluteobiceps & $3,203 \pm 579^{a}$ & 1. $304^{\mathrm{a}}$ & $30.7 \pm 4.1^{x c}$ & $40.0 \pm 2.7^{\text {xab }}$ & $29.3 \pm 5.4^{\mathrm{xab}}$ \\
\hline M. tensor fasciae latae & $574 \pm 97^{\mathfrak{e}}$ & $0.235^{\text {cdefg }}$ & $26.7 \pm 1.3^{y c}$ & $21.6 \pm 4.0^{\mathrm{xab}}$ & $51.6 \pm 2.9^{\mathrm{xa}}$ \\
\hline \multicolumn{6}{|l|}{ M. quadriceps femoris } \\
\hline M. rectus femoris & $940 \pm 143^{b c}$ & $0.386^{\mathrm{ce}}$ & $22.9 \pm 3.5^{y c}$ & $35.5 \pm 5.6^{\text {xyab }}$ & $41.6 \pm 3.7^{\mathrm{xab}}$ \\
\hline M. vastus lateralis & $1,021 \pm 175^{b c}$ & $0.417^{\mathrm{cd}}$ & 26.7 & 39.6 & 33.7 \\
\hline$M$. vastus intermedius & $133 \pm 33^{c}$ & $0.053^{g}$ & 97.2 & 2.5 & 0.3 \\
\hline M. vastus medialis & $530 \pm 93^{c}$ & $0.216^{\mathrm{deg}}$ & $42.7 \pm 2.9^{x b c}$ & $31.8 \pm 0.4^{\mathrm{yab}}$ & $25.5 \pm 3.0^{\text {yab }}$ \\
\hline M. semitendinosus & $1,169 \pm 254^{\mathrm{abc}}$ & $0.473^{c}$ & $29.3 \pm 0.7^{x c}$ & $27.8 \pm 5.4^{\mathrm{xab}}$ & $42.9 \pm 5.9^{\mathrm{xab}}$ \\
\hline M. semimembranosus & $2,242 \pm 338^{\mathrm{ab}}$ & $0.921^{\mathrm{b}}$ & $21.3 \pm 1.3^{y c}$ & $38.2 \pm 4.3^{\mathrm{xab}}$ & $40.5 \pm 1.6^{\text {xab }}$ \\
\hline M. sartorius & $192 \pm 27^{c}$ & $0.080^{\mathrm{g}}$ & $28.8 \pm 3.2^{x c}$ & $36.1 \pm 1.3^{\mathrm{xab}}$ & $35.1 \pm 2.4^{\mathrm{xab}}$ \\
\hline$M$, gracilis & $622 \pm 109^{c}$ & $0.254^{\text {cdefg }}$ & $28.0 \pm 2.6^{y c}$ & $47.3 \pm 4.6^{\mathrm{xa}}$ & $24.7 \pm 6.1^{\text {yab }}$ \\
\hline M. pectineus & $253 \pm 34^{c}$ & $0.105^{\mathrm{g}}$ & $32.1 \pm 4.6^{x c}$ & $31.9 \pm 1.9^{\mathrm{xab}}$ & $36.0 \pm 1.0^{x a b}$ \\
\hline M. adductor & $817 \pm 135^{b c}$ & $0.334^{\mathrm{dcf}}$ & $29.1 \pm 3.0^{\mathrm{xc}}$ & $35.0 \pm 2.9^{\text {xab }}$ & $35.9 \pm 1.7^{\mathrm{xab}}$ \\
\hline Mean \pm Standard Error & & & $39.8 \pm 5.0^{x}$ & $30.3 \pm 2.7^{x}$ & $29.9 \pm 2.9^{x}$ \\
\hline \multicolumn{6}{|l|}{ 2. Crusal Muscles } \\
\hline M. tibialis cranialis & $46 \pm 10^{c}$ & $0.019^{\mathrm{ef}}$ & $59.3 \pm 3.0^{x a b}$ & $19.0 \pm 4.3^{\mathrm{yab}}$ & $21.7 \pm 2.5^{y a}$ \\
\hline M. peroneus tertius & $148 \pm 27^{\mathrm{bc}}$ & $0.060^{\text {cd }}$ & $36.5 \pm 7.9^{x a c}$ & $23.0 \pm 8.2^{\mathrm{xab}}$ & $40.5 \pm 1.9^{x a}$ \\
\hline M. peroneus longus & $49 \pm 7^{c}$ & $0.020^{\mathrm{ef}}$ & $42.1 \pm 3.3^{\mathrm{xac}}$ & $24.3 \pm 3.1^{\text {yab }}$ & $33.6 \pm 6.4^{\text {xya }}$ \\
\hline M. extensor digitorum longus & $156 \pm 14^{\mathrm{bc}}$ & $0.065^{\mathrm{cd}}$ & $38.1 \pm 1.5^{\mathrm{xac}}$ & $25.0 \pm 6.0^{\mathrm{xab}}$ & $35.6 \pm 6.6^{\mathrm{xa}}$ \\
\hline M. extensor digitorum lateralis & $89 \pm 14^{c}$ & $0.038^{\text {de }}$ & $21.8 \pm 3.4^{\mathrm{xac}}$ & $31.9 \pm 3.2^{\mathrm{xab}}$ & $46.3+1.1^{\mathrm{xa}}$ \\
\hline \multicolumn{6}{|l|}{ M. triceps surae } \\
\hline \multicolumn{6}{|l|}{ M. gastrocnemius } \\
\hline Caput laterale & $441 \pm 62^{\mathrm{a}}$ & $0.182^{\mathrm{a}}$ & $21.6 \pm 3.9^{y c}$ & $33.7 \pm 1.3^{\text {xya }}$ & $44.8 \pm 5.1^{\text {xa }}$ \\
\hline Caput mediale & $372 \pm 59^{\mathrm{ab}}$ & $0.152^{b}$ & $29.7 \pm 3.9^{x b c}$ & $36.2 \pm 6.2^{\mathrm{xa}}$ & $34.1 \pm 2.6^{\text {xa }}$ \\
\hline M. soleus & $6 \pm 2^{c}$ & $0.002^{r}$ & $86.4 \pm 5.1^{\mathrm{xa}}$ & $6.5 \pm 1.5^{y b}$ & $7.1 \pm 4.2^{\mathrm{ya}}$ \\
\hline M. flexor digitorum superficalis & $176 \pm 32^{\mathrm{bc}}$ & $0.072^{c}$ & $38.5 \pm 2.2^{\mathrm{xbc}}$ & $49.2 \pm 8.8^{x a}$ & $12.3 \pm 6.6^{\mathrm{ya}}$ \\
\hline M. flexor digitorum profundus & $350 \pm 48^{\mathrm{ad}}$ & $0.145^{b}$ & $35.8 \pm 16.1^{\mathrm{xbc}}$ & $31.9+3.8^{\mathrm{xab}}$ & $32.3 \pm 9.4^{\mathrm{xa}}$ \\
\hline Mean \pm Standard Error & & & $41.0 \pm 6.1^{x}$ & 28. $1 \pm 3.6^{x}$ & $30.8 \pm 4.2^{x}$ \\
\hline
\end{tabular}

$\mathrm{n}=3$ Mean \pm Standard Error. $\mathrm{a}, \mathrm{b}, \mathrm{c}, \mathrm{d}, \mathrm{c}, \mathrm{f}, \mathrm{g}, \mathrm{x}, \mathrm{y}, *$ See the foot notes of Table 1. 


\section{Myofiber Type Composition in Young Steers}

each type in $\mathbf{M m}$. membri pelvini in young Japanese

\begin{tabular}{|c|c|c|}
\hline \multicolumn{3}{|c|}{ Diameter $(\mu \mathrm{m})$} \\
\hline Type I & Type II A & Type II B \\
\hline 37. $0 \pm 3.9^{x a}$ & $35.9 \pm 4.7^{x a}$ & $49.4 \pm 8.3^{x a}$ \\
\hline $45.5 \pm 1.9^{\mathrm{xa}}$ & $40.8 \pm 1.6^{x \mathrm{a}}$ & $43.8 \pm 1.3^{x a}$ \\
\hline $38.4 \pm 3.3^{\mathrm{xa}}$ & $38.1 \pm 3.5^{\mathrm{xa}}$ & $51.5 \pm 4.4^{\mathrm{xa}}$ \\
\hline $48.2 \pm 5.5^{\mathrm{xa}}$ & $52.5 \pm 4.2^{\mathrm{xa}}$ & $62.5 \pm 8.9^{\times a}$ \\
\hline $56.9 \pm 0.4^{\mathrm{xa}}$ & 53. $7 \pm 3.1^{\mathrm{xa}}$ & $58.1 \pm 2.7^{\text {xa }}$ \\
\hline 43. $0 \pm 3.9^{y a}$ & $35.9 \pm 4.7^{y a}$ & 49. $4 \pm 8.3^{x a}$ \\
\hline 35. $2 \pm 3.1^{\mathrm{xa}}$ & $36.9 \pm 1.7^{x a}$ & $46.2 \pm 0.5^{x a}$ \\
\hline 47. $1 \pm 3.9^{\mathrm{xa}}$ & $47.6 \pm 3.2^{\mathrm{xa}}$ & $59.2 \pm 2.7^{\mathrm{xa}}$ \\
\hline $34.0 \pm 2.0^{x a}$ & $37.7 \pm 3.0^{\mathrm{xa}}$ & $47.2 \pm 5.0^{\mathrm{xa}}$ \\
\hline 21.9 & 23.9 & 30.4 \\
\hline 27.8 & 23.1 & - \\
\hline $37.0 \pm 1.8^{\mathrm{xa}}$ & $43.4 \pm 2.5^{x a}$ & $47.4 \pm 4.0^{\times a}$ \\
\hline 49. $3 \pm 5.7^{\mathrm{xa}}$ & $53.5 \pm 8.4^{\mathrm{xa}}$ & 69. $2 \pm 12.4^{\mathrm{xa}}$ \\
\hline 37. $1 \pm 2.6^{\mathrm{xa}}$ & $38.5 \pm 3.7^{\mathrm{xa}}$ & $51.7 \pm 6.0^{\mathrm{xa}}$ \\
\hline $38.2 \pm 3.4^{\mathrm{xa}}$ & $41.0 \pm 2.6^{\mathrm{xa}}$ & 49. $1 \pm 3.4^{\text {xa }}$ \\
\hline $41.4 \pm 2.0^{\mathrm{xa}}$ & $39.1 \pm 1.6^{\mathrm{xa}}$ & $41.2 \pm 0.9^{\times a}$ \\
\hline $47.7 \pm 5.7^{\mathrm{xa}}$ & $47.6 \pm 3.6^{x a}$ & $53.8 \pm 5.7^{x a}$ \\
\hline $39.7 \pm 2.4^{y a}$ & $41.8 \pm 2.4^{y a}$ & $52.9 \pm 3.1^{\times a}$ \\
\hline $40.3 \pm 1.9^{y}$ & $40.6 \pm 2.0^{y}$ & $50.8 \pm 2.1^{x}$ \\
\hline $50.2 \pm 4.4^{\mathrm{xa}}$ & $41.5 \pm 4.3^{\mathrm{xa}}$ & $47.6 \pm 3.7^{\mathrm{xab}}$ \\
\hline $55.7 \pm 6.3^{x a}$ & $50.2 \pm 7.8^{x a}$ & $58.2 \pm 7.7^{\times a b}$ \\
\hline $52.4 \pm 3.1^{x a}$ & $53.6 \pm 5.2^{\mathrm{xa}}$ & $62.8 \pm 4.4^{\mathrm{xab}}$ \\
\hline 47. $1 \pm 0.8^{x y a}$ & $46.0 \pm 1.5^{y a}$ & $56.9 \pm 3.5^{\text {xab }}$ \\
\hline $48.3 \pm 5.2^{x y a}$ & $48.9 \pm 3.2^{y a}$ & $62.6 \pm 3.6^{x a b}$ \\
\hline $46.7 \pm 6.4^{\mathrm{xa}}$ & $44.7 \pm 6.7^{\times a}$ & $66.0 \pm 7.2^{\mathrm{xa}}$ \\
\hline 39. $3 \pm 4.1^{\mathrm{xa}}$ & $38.8 \pm 4.4^{\mathrm{xa}}$ & $51.5 \pm 3.4^{\mathrm{xab}}$ \\
\hline $37.9 \pm 4.8^{x a}$ & $44.2 \pm 4.5^{x a}$ & $51.5 \pm 3.5^{*}$ \\
\hline $49.9 \pm 1.9^{x a}$ & $45.6 \pm 2.9^{\text {xya }}$ & $41.2 \pm 1.9^{y b}$ \\
\hline $50.6 \pm 8.1^{x a}$ & $51.0 \pm 6.5^{\mathrm{xa}}$ & $54.1 \pm 5.9 *$ \\
\hline $47.8 \pm 1.7^{y}$ & $46.4 \pm 1.4^{y}$ & $55.2 \pm 2.4^{x}$ \\
\hline
\end{tabular}

others were almost Type IIA. When the forelimb steps forward and touches on the ground in locomotion or cattle graze with the head sustaining in standing posture, the carpal joint is exposed to its overextension generated by the gravity and the retractive power of the other muscles. These two muscles could play an important role of protecting from its overextension.

Mm. serratus ventrales (M. serratus ventralis cervicis and $\boldsymbol{M}$. serratus ventralis thoracis) at both sides suspend trunk between thoracic extremities. Half of myofibers in $M$. serratus ventralis thoracis were Type I with large size (Fig. 6). Mm. serratus ventrales was fairly large $(1,679 \mathrm{~g})$ in spite of containing Type I myofibers at high frequency (51\%). M. pectoralis descendens, a small muscle, also contained more myofibers as Type I $(67.7 \%)$ with large dimension. This small pectoral muscle seems to do sustaining attraction of thoracic extremity to trunk at shoulder for maintaining posture. The largest pectoral muscle, $M$. pectralis ascendens, is more active in retraction of thoracic extremity for locomotion because of high distribution of Type II myofibers.

In some muscles, the myofiber type composition in these young steers differed from that in the fattened ${ }^{6,7,8)}$. Generally the young muscle contained Type IIA myofibers at higher frequency. Some Type IIA myofibers seemed to transform into Type I or Type IIB with age ${ }^{20,21}$. The best development from 12 to 24 months of age was shown by $\mathrm{Mm}$. serratus ventrales with 2.40 time increase of the weight ${ }^{8}$. In $M$. serratus ventralis thoracis, some Type IIA myofibers were transformed into Type I from the young steers to the fattened. However, the cross sectional area occupied by Type I did not increase because of the different growth rates among the myofiber types (the young $70 \%$, the fattened $68 \%$ ). These results indicated that the posture maintaining function of $M$. serratus ventralis thoracis needs for the area of Type I myofibers to be kept at constant level and that the Type I myofibers could play sustaining contraction under enough oxygen supply from short distance of its diffusion. Myofiber transformation in this type were also shown by $M$. pectoralis acendens, $M$. logissimus thoracis, $M$. psoas major, M. iliacus, $M$. gluteus medius, $M$. rectus femoris, $M$. vastus medialis 
and $M$. peroneus tertius ${ }^{8}$. However, these muscles showed another phenomenon in the cross sectional area of Type I, in that its cross sectional area also increased by $7.2-22.2 \% \%^{8}$. The largest increase of the area was indicated by $M$. rectus femoris, an extensor of stifle joint, supposing development of the posture maintaining function. The myofiber transformation of Type IIA to Type IIB by $6.5-10.4 \%$ was also shown by $\boldsymbol{M}$. serratus ventralis thoracis, $\boldsymbol{M}$. supraspinatus, $\boldsymbol{M}$. gluteus medius, $M$. vastus medialis and the $M$. extensor digitalis longus ${ }^{8)}$. A marked increase in the cross sectional area of Type IIB was shown only by $M$. supraspinatus $(12.4 \%)$ and $M$. serratus ventralis thoracis $(9.2 \%)^{8)}$. The $M$. supraspinatus maintains the posture connecting between the Scapula and the Brachium, while $M$. serratus ventralis thoracis between Membrum thoracicum and Truncus. Therefore these muscle have a few Type IIB myofibers. Making up for it, the functional demand on Tyep IIB myofibers in these muscles may be still larger, as the cattle gain in the body weight with growth and fattening.

In conclusion, the young steers (11 months of age) have not yet gotten the same histochemical characteristic of skeletal muscle as shown by the fattened ( 24 months) $)^{8)}$ and also enough matured meat. The muscles with many Type I myofibers to play a main role for postural maintenance are usually very small and occupy the deep position near bone, but $\mathrm{Mm}$. serrarus ventrales is fairly large. The large muscles important for beef production such as $M$. gluteobiceps, $M$. longissimus thoracis, $\boldsymbol{M}$. semimembranosus and $\boldsymbol{M}$. pectoralis acendens contain great proportion of myofibers as Type II. These results suggest that every muscle attains its own histochemical characteristics to do its peculiar function at different body parts.

\section{References}

1) Ashmore CR, Tompkins G, Doerr L. Postnatal development of muscle fiber types in domestic animals. Journal of Animal Science, 34 : 37-41. 1972.

2) Brooke MH, Kaiser KK. Muscle fibre types: how many and what kind? Archives of Neurology, 23 : 369-379. 1970.

3) Brooke MH. Some comments on neural infuence on the two histochemical types of muscle fibers. In : The Physiology and Biochemistry of Muscle as a Food

Anim. Sci. J. $70(6): 497-509,1999$
Vol. 2 (Briskey EJ, Cassens RG, Marsh BB eds.) 131-153. The University of Wisconsin Press, Milwaukee and London. 1970.

4) Davies AS. Postnatal changes in the histochemical fibre types of porcine skeletal muscle. Journal of Anatomy, $113: 213-240.1972$.

5) Frewein J, Wille KH, Wilkens $\mathbf{H}$. Lehrbuch der Anatomie der Haustiere, Band I. Bewegungsapparat. Paul Parey. Berlin. 1984.

6) Gotoh $T$, Iwamoto H, Ono $Y$, Nishimura S, Matsuo K, Nakanishi Y, Umetsu R, Takahara H. Comparative study on the regional composition of fiber types in $M$. longissimus thoracis with different marbling scores for Japanese Black steers. Animal Science and Technology, 65: 454-463. 1994.

7) Gotoh $\mathrm{T}$, Iwamoto $\mathrm{H}$, Ono $\mathrm{Y}$, Nishimura S, Shigematsu I, Nakanishi Y, Umetsu R, Takahara H. Comparative study on the regional composition of fiber types in the cranial portion of $M$. biceps femoris in Japanese Black steers. Animal Science and Technology, $66: 62-71.1995$.

8) Iwamoto $H$, Ono $Y$, Gotoh $T$, Nishimura $S$, Nakanishi $Y$, Umetsu R, Takahara $H$. Comparative studies on the composition of muscle fiber types in Japanese Black, Japanese Brown and Holstein steers. Animal Science and Technology, 62:674-682. 1991.

9) Khan MA. Histochemical characteristics of vertebrate striated muscle: A review. Progress in Histochemistry and Cytochemistry, 8 (4) : 1-48. 1976.

10) Lopez-Rivero JL, Serramp AL, Diz AM, Galisteo AM. Variability of muscle fibre composition and fibre size in the horse gluteus medius : an enzymehistochemical and morphometric study. Journal of Anatomy, 181 : 1-10. 1992.

11) Manabe N, Kuribayashi $Y$, Miyamoto $M$, Kuramitsu K, Azuma Y, Furuya Y, Nagano N, Miyamoto $H$. Immunohistochemistry quantification of fast-myosin in frozen histological sections of goat hind limb muscles. Animal Science and Technology, 67 : 338352. 1996.

12) Peter JB, Barnard RJ, Edgerton VR, Gilespie CA, Stempel KE. Metabolic profiles of three fiber types of skeletal muscle in guinea-pigs and rabbits. Biochemistry, $11: 2627-2633.1972$.

13) Solomon MB, Campbell RG, Steele NC. Effect of sex and exogenous porcine somatotropin on Longissimus muscle fiber characteristics of growing pig. Journal of Animal Science, 68 : 1176-1181. 1990.

14) Suzuki A. Histochemical classification of individual 
skeletal muscle fibers in the sheep; I. On $M$. semitendinosus, M.longissimus dorsi, $\boldsymbol{M}$. psoas major, $M$. latissimus dorsi and $M$. gastrocnemius, Japanese Journal of Zootechnical Science, 42 : 39-54. 1971.

15) Suzuki A. Histochemical classification of individual skeletal muscle fibers in sheep; II. On $M$. serratus ventralis, $\boldsymbol{M}$. supraspinatus, $M$. infraspinatus, $\boldsymbol{M}$. semimembranosus and $M$. triceps brachii. Japanese Journal of Zootechnical Science, 42 : 463-473. 1971.

16) Suzuki A. Histochemistry of the chicken skeletal muscles ; I. Classification of individual muscle fibers. Tohoku Journal of Agricultural Resarch, 23 : 45-57. 1972.

17) Suzuki A. Histochemical observations of individual skeletal muscle fibers in starved sheep. Japanese Journal of Zootechnical Science, 44 : 50-58. 1973.

18) Suzuki A, Tamate H, Okada M. The effect of a high plane of nutrition during a given period of growth on size and proportion of skeletal muscle fiber types in the cattle. Tohoku Journal of Agricultural Research, 27 : 20-25. 1976

19) Suzuki A. The $\mathrm{pH}$ stability of myofibrilar adenosine triphosphatase of five fiber types in skeletal muscles of the sheep and cattle. Japanese Journal of Zootechnical Science, 47 : 95-103. 1976.

20) Suzuki A, Cassens RG. A histochemical study of myofiber types in muscle of the growing pig. Journal of Animal Science, 51 : 1449-1461. 1980.

21) Suzuki A, Cassens RG. Histochemical study of myofiber types in the serratus ventralis thoracis muscle of sheep during growth. Journal of Animal Science, $56:$ 1447-1458. 1983.

22) Suzuki $A$, Tsuchiya $T$, Ohwada $S$, Tamate H. Distribution of myofiber types in thigh muscles of chickens. Journal of Morphology, 185 : 145-154. 1985.

23) Suzuki A, Tamate H. Distribution of myofiber type in the hip and thigh musculature of sheep. The Anatomical Record, 221 : 494-502. 1988.

24) Suzuki A. Composition of myofiber types in the pectoral girdle musculature of sheep. The Anatomical Record, $230: 339-346.1991$.

25) Vollestad NK. Moter unit recruitment; a histochemical approach. In : Medicine and Sport Science. (Hebbelinck M, Shephard RJ eds.) vol. 26 (Muscular Function in Exercise and Training : Marconnet P, Komi PV eds.) 128-141. Karger press. Switzerland. 1987.

26) Winters JM, Woo SL-Y. Multiple Muscle Systems : Biomechanics and Movement Organization. 498506. Springer-Verlag. New York. 1990.

27) Young OA, Bass JJ. Effect of castration on bovine composition. Meat Science, 11 : 139-156. 1984. 